\title{
The Role of Anti-Obesity Medication in Prevention of Diabetes and Its Complications
}

Tae Jung $\mathrm{Oh}^{*}$

Department of Internal Medicine, Seoul National University College of Medicine, Seoul; Department of Internal Medicine, Seoul National University Bundang Hospital, Seongnam, Korea

Diabetes is prevalent in obese population, and obesity management is the first step in preventing diabetes. Traditionally, lifestyle modification including reduced-calorie diet, physical activity, and behavior intervention is the core of obesity management. However, pharmacotherapy is frequently required in addition to the lifestyle modification for effective reduction of body weight. There are five classes of anti-obesity medications approved by the U.S. Food and Drug Administration for chronic treatment used in obesity management. As the goal of obesity management is to prevent obesity-related comorbidities, clinical trials were conducted to evaluate the effect of anti-obesity medications on cardiovascular risk factors including hyperglycemia. Orlistat and liraglutide have been tested for their effect on diabetes prevention as a primary outcome. Cardiovascular safety studies were conducted for lorcaserin and liraglutide (as an anti-diabetic medication). In addition, there are many indirect evidences of the role of anti-obesity medications on diabetes prevention and its microvascular and macrovascular complications. This review focused on current evidences of anti-obesity medications related with diabetes, which is a major complication of obesity.

Key words: Obesity, Diabetes mellitus, Drug therapy, Cardiovascular disease, Diabetes complications

Received July 15, 2019

Reviewed August 10, 2019

Accepted August 25, 2019

${ }^{*}$ Corresponding author

Tae Jung Oh

https://orcid.org/0000-0002-5078-6123

Department of Internal Medicine, Seoul National University College of Medicine and Department of Internal Medicine, Seoul National University Bundang Hospital, 82 Gumi-ro 173beon-gil, Bundang-gu, Seongnam 13620, Korea Tel: +82-31-787-7078

Fax: +82-31-787-4050

E-mail: ohtjmd@gmail.com

\section{INTRODUCTION}

The prevalence of obesity has doubled since 1980 and this trend has continued over time. ${ }^{1}$ This is a serious global health problem and we need appropriate prevention strategies for obesity itself and obesity related comorbidities. Diabetes is the most hazardous obesity related comorbidity and it can be prevented by reducing body weight. ${ }^{2,3}$ Furthermore, for the individuals who already suffer from diabetes, a larger body weight reduction brought a better glucose control and health benefit on one year ${ }^{4}$ and even longer term. ${ }^{5}$ Reducing hyperglycemia is one of the most important prevention strategies for diabetes complications. ${ }^{6,7}$ Moreover, obesity management is important not only for the prevention of diabetes but also for the delay of diabetes related complications.

Life style modification including healthy meal plan, increase of physical activity, and behavior intervention is an essential part of obesity management. ${ }^{8}$ However, majority of patients need pharmacotherapy to control their body weight effectively. Currently, there are five classes of pharmacotherapy for obesity, which have been approved by the U.S. Food and Drug Administration (FDA) for chronic treatment. These are orlistat, lorcaserin, phentermine/topiramate extended-release (ER), naltrexone sustained release (SR)/ bupropion SR, and liraglutide $3.0 \mathrm{mg}$. In this review, I focused on the evidence and mechanistic explanation of each drug in preventing diabetes and its complications.

Copyright @ 2019 Korean Society for the Study of Obesity

(a) This is an Open Access article distributed under the terms of the Creative Commons Attribution Non-Commercial License (http://creativecommons.org/licenses/by-nc/4.0/) which permits unrestricted non-commercial use, distribution, and reproduction in any medium, provided the original work is properly cited. 
Table 1. Anti-obesity medications and its role in diabetes prevention

\begin{tabular}{|c|c|c|c|c|c|c|c|}
\hline Drug & Study name & Time to diabetes & Subject & $\begin{array}{l}\text { Baseline BMl of } \\
\text { treatment group } \\
\left(\mathrm{kg} / \mathrm{m}^{2}\right)\end{array}$ & $\begin{array}{l}\text { Body weight } \\
\text { change }\end{array}$ & $\begin{array}{l}\text { Follow-up } \\
\text { duration }\end{array}$ & $\mathrm{HR}(95 \% \mathrm{Cl})$ \\
\hline Orlistat & XENDOS & Primary outcome & $\begin{array}{l}\text { 3,305 Subjects with normal }(79 \%) \text { and } \\
\text { prediabetes }(21 \%)\end{array}$ & 37.3 & $-5.8 \mathrm{~kg}$ & $4 \mathrm{yr}$ & $0.63(0.46-0.86)$ \\
\hline $\begin{array}{l}\text { Phentermine/ } \\
\text { topiramate ER }\end{array}$ & CONOUER & $\begin{array}{l}\text { Secondary outcome } \\
\text { of subgroup }\end{array}$ & 2,092 Subjects with normal and prediabetes & 36.6 & $-10.2 \mathrm{~kg}^{*}$ & 56 wk & $0.47(0.25-0.88)$ \\
\hline Lorcaserin & CAMELLIA-TIMI 61 & Secondary outcome & 3,991 Subjects with prediabetes & 34.0 & $\begin{array}{c}-2.8 \mathrm{~kg} \\
\text { (compared to placebo) }\end{array}$ & $3.3 \mathrm{yr}$ & $0.81(0.66-0.99)$ \\
\hline Liraglutide & SCALE & Primary outcome & 2,254 Subjects with prediabetes & 38.8 & $-6.1 \%$ & $160 w k$ & $0.21(0.13-0.34)$ \\
\hline
\end{tabular}

*This data was driven in high-dose treatment subjects including diabetes.

BMI, body mass index; HR, hazard ratio; Cl, confidence interval; XENDOS, Xenical in the Prevention of Diabetes in Obese Subjects; ER, extended-release

\section{PREVENTION OF DIABETES}

The Finnish Diabetes Prevention Study (DPS) and Diabetes Prevention Program (DPP) demonstrated that intensive lifestyle modification reduced the incidence of diabetes by $58 \%$ compared to placebo during around 3 years., ${ }^{9}$ The study participants of DPS were given detailed advice to reduce their body weight by $5 \%$ or more including dietary advice and individual guidance for physical activity ${ }^{10}$ In DPP, subjects participated a 16-session one to one curriculum of diet, exercise, and behavioral modification to achieve the goal of body weight reduction (at least 7\% of baseline body weight). ${ }^{9}$ They were encouraged to follow healthy low calorie, lowfat diet and at least 150 minutes of moderate intensity exercise per week. At the end of study, the body weight loss from the baseline was $4.2 \mathrm{~kg}$ in DPS and $5.6 \mathrm{~kg}$ in DPP. Therefore, life style modification is generally recommended to prevent diabetes. However, the success of life style modification is hardly achieved without a supervised program. ${ }^{11}$ Therefore, pharmacotherapy is necessary in many situations. Some of the anti-obesity medications were evaluated for their role in prevention of diabetes as a primary or secondary outcomes (Table 1).

\section{Orlistat}

Orlistat was approved in 1999 by the FDA as an anti-obesity medication. Orlistat is a lipase inhibitor, which prevents the absorption of dietary fat. Moreover, it is the only peripheral acting antiobesity medication. ${ }^{12}$ According to two phase III studies performed in European countries ${ }^{13}$ and the USA, ${ }^{14}$ it has been proved that orlistat promotes a significant weight loss and improves hyperglyce- mia in obese subjects. A pooled analysis ${ }^{15}$ including these two studies showed that subjects with impaired glucose tolerance (IGT) less progressed to diabetes in orlistat group than the placebo group ( $3.0 \%$ vs. $7.6 \%, P=0.04$ ). More directly, a 4-year, double-blind, placebo-controlled randomized study named Xenical in the Prevention of Diabetes in Obese Subjects (XENDOS) study ${ }^{16}$ demonstrated the role of orlistat in diabetes prevention. Orlistat $120 \mathrm{mg}$ had an incidence reduction of diabetes by $37.3 \%$ compared to placebo (hazard ratio $[\mathrm{HR}], 0.63 ; 95 \%$ confidence interval $[\mathrm{CI}]$, 0.46-0.86). This study included both normal glucose tolerance (NGT) and IGT. In the subgroup analysis, the impact of orlistat in the prevention of diabetes was greater in the IGT group (HR, 0.482 ) despite the similar magnitude of body weight reduction between subjects with NGT and those with IGT, 5.8 and $5.7 \mathrm{~kg}$, respectively. The greater risk reduction effect might be derived in high risk subjects for diabetes. Possible mechanisms for diabetes prevention except body weight reduction were reducing postprandial lipidemia, ${ }^{17}$ decreasing inflammatory cytokines, ${ }^{18}$ and increasing postprandial glucagon-like peptide-1 (GLP-1) secretion ${ }^{19}$ after orlistat treatment.

\section{Phentermine/topiramate ER}

Phentermine/topiramate ER is a single-pill combination of phentermine, sympathomimetic amine and topiramate, an antiepileptic drug. This drug was approved for anti-obesity medication in 2012. There were two large scale randomized double-blind, placebo-controlled studies to prove the efficacy of body weight reduction of phentermine/topiramate ER in overweight or obese subjects. ${ }^{20,21}$ However, there was no study to assess the prevention of 
diabetes as a primary outcome. The CONQUER study enrolled $84 \%$ of subjects without type 2 diabetes at baseline. ${ }^{20}$ In this population, development of diabetes was less in phentermine $15 \mathrm{mg} /$ topiramate ER $92 \mathrm{mg}$ (1.7\%) group than placebo (3.6\%; HR, 0.47; $95 \%$ CI, $0.25-0.88$ ) during the 56 weeks. A total of $78.1 \%$ of subjects in CONQUER study continued to take blinded medication over 108 weeks to evaluate the long-term efficacy and safety of phentermine/topiramate ER and the name of this extended study is SEQUEL. ${ }^{22}$ In the SEQUEL study, the least square mean percentage changes of body weight from baseline were greater in high dose Phentermine/topiramate ER than placebo ( $-10.5 \%$ vs. $-1.8 \%, P<0.001)$. The annualized incidence rates for progression to type 2 diabetes in subjects without type 2 diabetes at baseline were $0.9 \%$ in high dose phentermine/topiramate ER group and $3.7 \%$ in the placebo group $(P=0.008)$. Therefore, phentermine 15 $\mathrm{mg} /$ topiramate ER $92 \mathrm{mg}$ showed a continuously decreasing rate of the newly developed type 2 diabetes for a 2-year observation. Subgroup analysis including subjects with prediabetes and/or metabolic syndrome at baseline showed that the annual incidence rate of type 2 diabetes was 1.3 for high dose phentermine/topiramate and 6.1 in placebo. ${ }^{23}$ The reduction rate is likely to be exaggerated in high risk subjects for diabetes. From the data of pooled analysis of phase III studies, only 24 were needed to be treated to prevent one event of new type 2 diabetes for 56 weeks in the highest risk group in contrast to the number needed to be treated increasing up to 120 in the lowest risk group. ${ }^{24}$ In addition, greater body weight loss was associated with greater reduction in progression to type 2 diabetes. In this regard, it is necessary to find appropriate subjects to have good adherence to the medication in a longer term of use among subjects at having high risk of diabetes.

\section{Lorcaserin}

Lorcaserin is a 5-hyroxytryptamine receptor $2 \mathrm{C}$ agonist. This drug stimulates proopiomelanocortin (POMC) neurons in the hypothalamus and decreases appetite. ${ }^{25}$ This drug was approved as an anti-obesity medication in 2012. Two phase III studies ${ }^{26,27}$ including overweight and obese subjects without diabetes and one phase III study ${ }^{28}$ including those with diabetes were conducted and chronic treatment (1-year and 2-year) with lorcaserin reduced more body weight compared to placebo (5\%-6\% vs. $1 \%-2 \%)$. Af- ter these studies, CAMELLIA-TIMI 61 study was conducted independently to assess the cardiovascular safety and efficacy of lorcaserin. ${ }^{29}$ Among the study population, the prespecified primary metabolic efficacy, which is evaluated as the time to incident type 2 diabetes, was analyzed in 3,991 subjects with prediabetes at baseline. ${ }^{30}$ During a median follow-up of 3.3 years, lorcaserin reduced the risk of incidence of diabetes by $19 \%$ (HR, 0.81 ; $95 \%$ CI, $0.66-$ 0.99). Furthermore, remission rate of hyperglycemia was higher in lorcaserin treatment than placebo in subjects with type 2 diabetes at baseline (HR, 1.21; 95\% CI, 1.07-1.36). ${ }^{30}$ Interestingly, glycosylated hemoglobin ( $\mathrm{HbAlc})$ reduction occurred earlier than significant weight loss. From a preclinical study, lorcaserin suppressed hepatic glucose production via melanocortin 4 receptor signaling, which phenomenon was independent to its anorectic effect. ${ }^{31}$ Therefore, lorcaserin might have direct mechanism to reduce hyperglycemia in improving insulin sensitivity.

\section{Naltrexone SR/bupropion SR}

Naltrexone blocks the opioid-mediated POMC auto-inhibition and bupropion stimulates the hypothalamic POMC neuron. Combination of these two drugs showed synergistic effects in body weight reduction, ${ }^{32}$ and was approved as an anti-obesity medication in 2014. There were four Contrave Obesity Research (COR) studies. The COR-I, ${ }^{33}$ COR-II, ${ }^{34}$ and COR-behavior modification ${ }^{35}$ included subjects without diabetes. Among these studies, only COR-I study showed a significant decrease of fasting plasma glucose in naltrexone SR $32 \mathrm{mg} /$ bupropion SR $16 \mathrm{mg}$ combination treatment, but all three of the studies did not evaluate the incidence of diabetes. According to COR-Diabetes study ${ }^{36}$ including subjects with type 2 diabetes under lifestyle modification and/or oral antidiabetic medications, HbAlc levels decreased more in naltrexone SR/bupropion SR combination treatment than in placebo after 1-year $(-0.6 \%$ vs. $-0.1 \%, P<0.001)$. However, there was no data about the remission rate of diabetes. Further longer-term study will be necessary to establish the effect of this medication on diabetes prevention. In summary, even though it exhibited comparable effects on body weight reduction when it was indirectly compared to other anti-obesity medication, there is very limited data of naltrexone SR/bupropion SR combination treatment for its effect on diabetes prevention. ${ }^{37}$ 


\section{Liraglutide}

Liraglutide is a GLP-1 receptor agonist and it has been first approved as an anti-diabetic medication. ${ }^{38}$ Higher dose of liraglutide (3.0 mg per day) showed greater body weight loss in a phase 2 study and the magnitude of body weight reduction was greater than orlistat. ${ }^{39}$ Following the SCALE study, a large scaled randomized double-blind, placebo-controlled study, confirmed that $3.0 \mathrm{mg}$ of liraglutide effectively reduced body weight compared to the placebo (a difference of $-5.6 \mathrm{~kg}$; $95 \% \mathrm{CI},-6.0$ to $-5.1 \mathrm{~kg} ; P<0.001) .{ }^{40}$ Subjects with prediabetes at baseline $(n=2,254)$ continued on liraglutide $3.0 \mathrm{mg}$ or placebo for 2 more years. ${ }^{41}$ The risk of diabetes was much lower in liraglutide group than the placebo group (HR, 0.21; 95\% CI, 0.13-0.34; $P<0.001)$. This significant difference remained after a 12-week follow-up after discontinuation of treatment. In this period, decrease of insulin resistance was maintained. Furthermore, liraglutide induced more regression from prediabetes to normoglycemia than placebo (odds ratio, 3.6; 95\% CI, 3.0-4.4; $P<0.001)$. The amount of body weight reduction in those with newly developed diabetes was less than those who were not diagnosed with diabetes in each treatment group, which might implicate that body weight reduction play a primary role in delay of diabetes. Therefore, body weight reduction might have a primary role in delay of diabetes. In addition, GLP-1 showed a beta-cell preservation effect in preclinical ${ }^{42}$ and clinical studies. ${ }^{43,44}$ Taken together, chronic treatment with liraglutide might improve both beta-cell function and insulin sensitivity followed by body weight reduction and finally prevent diabetes in high risk patients.

\section{PREVENTION OF DIABETES COMPLICATIONS}

Not only intensive glycemic control ${ }^{45}$ but also effective management of high blood pressure and dyslipidemia ${ }^{46}$ can reduce the risk of chronic diabetic complications. Therefore, anti-obesity medications have a potential role in delaying the diabetes related complications (Fig. 1).

\begin{tabular}{|l|l|}
\hline Orlistat & PP2 $10.8 \mathrm{mg} / \mathrm{dL}$ \\
\hline Phentermine/topiramate ER & FPG $1.3 \mathrm{mg} / \mathrm{dL}$ \\
\hline Lorcaserin & FPG $0.8 \mathrm{mg} / \mathrm{dL}$ \\
\hline Naltrexone SR/bupropion SR & FPG $3.2 \mathrm{mg} / \mathrm{dL}$ \\
\hline Liraghutide & FPG $7.1 \mathrm{mg} / \mathrm{dL}$ \\
\hline
\end{tabular}

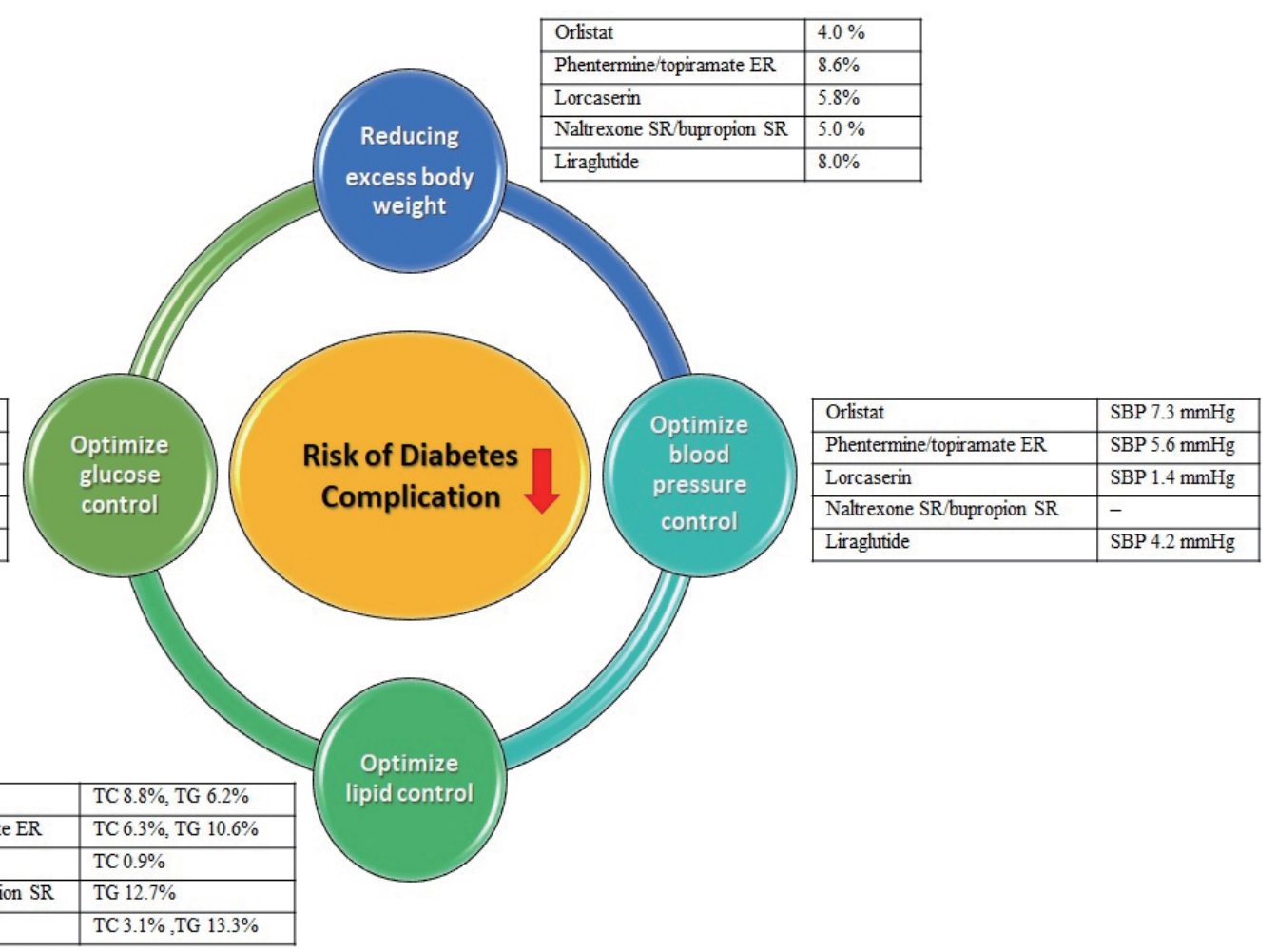

Figure 1. The role of anti-obesity medications on diabetes complication risk management. Data from XENDOS (orlistat), ${ }^{16}$ CONQUER (phentermine/topiramate extendedrelease $[\mathrm{ER}]{ }_{1}^{20} \mathrm{BLOOM}$ (lorcaserin), ${ }_{1}^{26} \mathrm{COR}$ (naltrexone SR/bupropion SR), ${ }_{1}^{33}$ and SCALE (liraglutide). ${ }^{40} \mathrm{ER}$, extended-release; SR, sustained release; PP2, postprandial 2 hourplasma glucose; FPG, fasting plasma glucose; SBP, systolic blood pressure; TC, total cholesterol; TG, triglyceride; XENDOS, Xenical in the Prevention of Diabetes in Obese Subjects; COR, Contrave Obesity Research. 
Table 2. Anti-obesity medications and its role in diabetes microvascular complications

\begin{tabular}{|c|c|c|c|}
\hline Author (year) & Drug & Outcome measurement & Result \\
\hline Tong et al. $(2002)^{47}$ & Orlistat & The $\%$ change of 24 -hour urine albumin excretion from baseline & $\begin{array}{l}-3.1 \% \text { In subjects with diabetes and }-6.7 \% \text { in subjects without } \\
\text { diabetes }\end{array}$ \\
\hline Scirica et al. (2019) & Lorcaserin & $\begin{array}{l}\text { Composite of new or worsening persistent micro- or macroalbuminuria, } \\
\text { new or worsening CKD, doubling of serum creatinine, ESRD, renal } \\
\text { transplant, or renal death }\end{array}$ & $\mathrm{HR}, 0.87(95 \% \mathrm{Cl}, 0.79-0.96 ; P=0.006)$ \\
\hline Mann et al. $(2017)^{49}$ & Liraglutide & $\begin{array}{l}\text { Composite of new persistent macroalbuminuria, persistent doubling of } \\
\text { serum creatinine, ESRD, or renal death }\end{array}$ & $\mathrm{HR}, 0.78(95 \% \mathrm{Cl}, 0.67-0.92 ; P=0.004)$ \\
\hline
\end{tabular}

CKD, chronic kidney disease; ESRD, end-stage renal disease; $\mathrm{HR}$, hazard ratio; $\mathrm{Cl}$, confidence interval.

\section{Orlistat}

Cardiovascular risk factors were assessed after a 1-year treatment of orlistat in subjects with diabetes. ${ }^{50}$ Total and low-density lipoprotein cholesterol, and systolic blood pressure were significantly reduced in orlistat group than the placebo group. ${ }^{47}$ In this study, 24-hour urine albumin excretion was also significantly decreased after orlistat treatment (Table 2). Therefore, orlistat induced weight reduction effectively and also controlled cardiovascular risk factors. However, there was no large scale randomized controlled trial to evaluate the major adverse cardiovascular events (MACE).

\section{Phentermine/topiramate ER}

A retrospective study comparing MACE among phentermine/ topiramate ER fixed dose combination, each component use, and unexposed to each drug demonstrated that phentermine/topiramate ER did not increase MACE. ${ }^{24}$ However, there was no study to demonstrate the effect of drug on diabetic microvascular and macrovascular complications.

\section{Lorcaserin}

In CAMELLIA-TIMI 61 study microvascular composite outcome (Table 2) including persistent microalbuminuria, diabetic retinopathy, and diabetic neuropathy reduced in lorcaserin than placebo (HR, 0.79; 95\% CI, 0.69-0.92). ${ }^{30}$ Among them, renal composite outcome was also solely reduced in lorcaserin group than the placebo group (HR, 0.87; 95\% CI, 0.79-0.96). ${ }^{48}$ This renal protective effect was globally observed across subgroups according to cardiovascular and renal risk. In summary, lorcaserin treatment was associated with reducing diabetic microvascular complications and did not increase MACE.

\section{Naltrexone SR/bupropion SR}

From June, 2012, cardiovascular safety study was started to determine whether naltrexone SR/bupropion SR combination treatment increases major cardiovascular adverse cardiovascular events. ${ }^{51}$ According to the $50 \%$ interim analysis, HR of MACE associated with treatment of naltrexone SR/bupropion SR was 0.88 (95\% CI, 0.57-1.34). However, due to early termination of the study, we have no conclusive result about cardiovascular safety of naltrexone SR/bupropion SR. Therefore, there is very limited data of naltrexone SR/bupropion SR combination treatment for the effect on cardiovascular safety.

\section{Liraglutide}

Liraglutide was firstly developed as anti-diabetic medication, and its cardiovascular safety data has been published. ${ }^{52}$ Liraglutide Effect and Action in Diabetes: Evaluation of Cardiovascular Outcome Results (LEADER) trial demonstrated the cardiovascular safety and superiority of liraglutide $1.8 \mathrm{mg}$ compared to placebo (HR, 0.87; 95\% CI, 0.78-0.97). However, dosage of anti-obesity medication of liraglutide is much higher than anti-diabetic medication, which is $3.0 \mathrm{mg}$. Therefore, we cannot guarantee the cardiovascular safety or benefit of liraglutide $3.0 \mathrm{mg}$ adopting the LEADER trial. A post hoc analysis of SCALE study showed no association between the chronic treatment with liraglutide $3.0 \mathrm{mg}$ and the adverse cardiovascular events ( $\mathrm{HR}, 0.42$; 95\% CI, 0.17-1.08).$^{53}$ This analysis showed a broad range of CI because SCALE study enrolled subjects with relatively low cardiovascular risk compared to subjects enrolled in LEADER study. According to the available data, liraglutide as an anti-obesity medication at least did not increase cardiovascular events in long term use. Furthermore, prespecified secondary renal outcomes in LEADER trial were less de- 
tected in liraglutide than placebo (HR, 0.78; 95\% CI, 0.67-0.92), ${ }^{49}$ in which the results were mainly derived by reducing albuminuria (Table 2). Likewise, the higher dose regimen of liraglutide has not been studied, whether it reduces diabetic complications as prespecified outcomes.

\section{CONCLUSION}

Since obesity is the most important risk factor for type 2 diabetes, many anti-obesity medications have been tested for their role in diabetes prevention. In addition, the effect of anti-obesity medications on diabetes related complications have been demonstrated. Many of them showed neutral effect on cardiovascular events. However, further large scale long term studies should be performed to prove their roles in cardiovascular disease and microvascular complications as well.

\section{CONFLICTS OF INTEREST}

The author declares no conflict of interest.

\section{REFERENCES}

1. GBD 2015 Obesity Collaborators, Afshin A, Forouzanfar MH, Reitsma MB, Sur P, Estep K, et al. Health effects of overweight and obesity in 195 countries over 25 years. N Engl J Med 2017; 377:13-27.

2. Diabetes Prevention Program Research Group, Knowler WC, Fowler SE, Hamman RF, Christophi CA, Hoffman HJ, et al. 10-Year follow-up of diabetes incidence and weight loss in the Diabetes Prevention Program Outcomes Study. Lancet 2009; 374:1677-86.

3. American Diabetes Association. 3. Prevention or delay of type 2 diabetes: Standards of Medical Care in Diabetes-2019. Diabetes Care 2019;42(Suppl 1):S29-33.

4. Wing RR, Lang W, Wadden TA, Safford M, Knowler WC, Bertoni AG, et al. Benefits of modest weight loss in improving cardiovascular risk factors in overweight and obese individuals with type 2 diabetes. Diabetes Care 2011;34:1481-6.

5. Look AHEAD Research Group, Wing RR, Bolin P, Brancati
FL, Bray GA, Clark JM, et al. Cardiovascular effects of intensive lifestyle intervention in type 2 diabetes. N Engl J Med 2013; 369:145-54.

6. UK Prospective Diabetes Study (UKPDS) Group. Intensive blood-glucose control with sulphonylureas or insulin compared with conventional treatment and risk of complications in patients with type 2 diabetes (UKPDS 33). Lancet 1998;352: 837-53.

7.ADVANCE Collaborative Group, Patel A, MacMahon S, Chalmers J, Neal B, Billot L, et al. Intensive blood glucose control and vascular outcomes in patients with type 2 diabetes. N Engl J Med 2008;358:2560-72.

8. Garvey WT, Mechanick JI, Brett EM, Garber AJ, Hurley DL, Jastreboff AM, et al. American Association of Clinical Endocrinologists and American College of Endocrinology comprehensive clinical practice guidelines for medical care of patients with obesity. Endocr Pract 2016;22 Suppl 3:1-203.

9. Knowler WC, Barrett-Connor E, Fowler SE, Hamman RF, Lachin JM, Walker EA, et al. Reduction in the incidence of type 2 diabetes with lifestyle intervention or metformin. $\mathrm{N}$ Engl J Med 2002;346:393-403.

10. Tuomilehto J, Lindström J, Eriksson JG, Valle TT, Hämäläinen $\mathrm{H}$, Ilanne-Parikka P, et al. Prevention of type 2 diabetes mellitus by changes in lifestyle among subjects with impaired glucose tolerance. N Engl J Med 2001;344:1343-50.

11. Wadden TA, Butryn ML, Byrne KJ. Efficacy of lifestyle modification for long-term weight control. Obes Res 2004;12 Suppl: 151S-162S.

12. Heck AM, Yanovski JA, Calis KA. Orlistat, a new lipase inhibitor for the management of obesity. Pharmacotherapy 2000;20: 270-9.

13. Sjöström L, Rissanen A, Andersen T, Boldrin M, Golay A, Koppeschaar HP, et al. Randomised placebo-controlled trial of orlistat for weight loss and prevention of weight regain in obese patients: European Multicentre Orlistat Study Group. Lancet 1998;352:167-72.

14. Davidson MH, Hauptman J, DiGirolamo M, Foreyt JP, Halsted $\mathrm{CH}$, Heber D, et al. Weight control and risk factor reduction in obese subjects treated for 2 years with orlistat: a randomized controlled trial. JAMA 1999;281:235-42. 
15. Heymsfield SB, Segal KR, Hauptman J, Lucas CP, Boldrin MN, Rissanen A, et al. Effects of weight loss with orlistat on glucose tolerance and progression to type 2 diabetes in obese adults. Arch Intern Med 2000;160:1321-6.

16. Torgerson JS, Hauptman J, Boldrin MN, Sjöström L. XENical in the prevention of diabetes in obese subjects (XENDOS) study: a randomized study of orlistat as an adjunct to lifestyle changes for the prevention of type 2 diabetes in obese patients. Diabetes Care 2004;27:155-61.

17. Tan KC, Tso AW, Tam SC, Pang RW, Lam KS. Acute effect of orlistat on post-prandial lipaemia and free fatty acids in overweight patients with type 2 diabetes mellitus. Diabet Med 2002; 19:944-8.

18. Samuelsson L, Gottsäter A, Lindgärde F. Decreasing levels of tumour necrosis factor alpha and interleukin 6 during lowering of body mass index with orlistat or placebo in obese subjects with cardiovascular risk factors. Diabetes Obes Metab 2003;5:195-201.

19. Damci T, Yalin S, Balci H, Osar Z, Korugan U, Ozyazar M, et al. Orlistat augments postprandial increases in glucagon-like peptide 1 in obese type 2 diabetic patients. Diabetes Care 2004; 27:1077-80.

20. Gadde KM, Allison DB, Ryan DH, Peterson CA, Troupin B, Schwiers ML, et al. Effects of low-dose, controlled-release, phentermine plus topiramate combination on weight and associated comorbidities in overweight and obese adults (CONQUER): a randomised, placebo-controlled, phase 3 trial. Lancet 2011;377:1341-52.

21. Allison DB, Gadde KM, Garvey WT, Peterson CA, Schwiers $\mathrm{ML}$, Najarian T, et al. Controlled-release phentermine/topiramate in severely obese adults: a randomized controlled trial (EQUIP). Obesity (Silver Spring) 2012;20:330-42.

22. Garvey WT, Ryan DH, Look M, Gadde KM, Allison DB, Peterson CA, et al. Two-year sustained weight loss and metabolic benefits with controlled-release phentermine/topiramate in obese and overweight adults (SEQUEL): a randomized, placebo-controlled, phase 3 extension study. Am J Clin Nutr 2012; 95:297-308.

23. Garvey WT, Ryan DH, Henry R, Bohannon NJ, Toplak H, Schwiers M, et al. Prevention of type 2 diabetes in subjects with prediabetes and metabolic syndrome treated with phentermine and topiramate extended release. Diabetes Care 2014; 37:912-21.

24. Ritchey ME, Harding A, Hunter S, Peterson C, Sager PT, Kowey PR, et al. Cardiovascular safety during and after use of phentermine and topiramate. J Clin Endocrinol Metab 2019; 104:513-22.

25. Thomsen WJ, Grottick AJ, Menzaghi F, Reyes-Saldana H, Espitia S, Yuskin D, et al. Lorcaserin, a novel selective human 5-hydroxytryptamine $2 \mathrm{C}$ agonist: in vitro and in vivo pharmacological characterization. J Pharmacol Exp Ther 2008;325: 577-87.

26. Smith SR, Weissman NJ, Anderson CM, Sanchez M, Chuang E, Stubbe S, et al. Multicenter, placebo-controlled trial of lorcaserin for weight management. N Engl J Med 2010;363:245-56.

27. Fidler MC, Sanchez M, Raether B, Weissman NJ, Smith SR, Shanahan WR, et al. A one-year randomized trial of lorcaserin for weight loss in obese and overweight adults: the BLOSSOM trial. J Clin Endocrinol Metab 2011;96:3067-77.

28. O’Neil PM, Smith SR, Weissman NJ, Fidler MC, Sanchez M, Zhang J, et al. Randomized placebo-controlled clinical trial of lorcaserin for weight loss in type 2 diabetes mellitus: the BLOOM-DM study. Obesity (Silver Spring) 2012;20:1426-36.

29. Bohula EA, Wiviott SD, McGuire DK, Inzucchi SE, Kuder J, Im K, et al. Cardiovascular safety of lorcaserin in overweight or obese patients. N Engl J Med 2018;379:1107-17.

30. Bohula EA, Scirica BM, Inzucchi SE, McGuire DK, Keech AC, Smith SR, et al. Effect of lorcaserin on prevention and remission of type 2 diabetes in overweight and obese patients (CAMELLIA-TIMI 61): a randomised, placebo-controlled trial. Lancet 2018;392:2269-79.

31. Burke LK, Ogunnowo-Bada E, Georgescu T, Cristiano C, de Morentin PB, Valencia Torres L, et al. Lorcaserin improves glycemic control via a melanocortin neurocircuit. Mol Metab 2017;6:1092-102.

32. Greenway FL, Whitehouse MJ, Guttadauria M, Anderson JW, Atkinson RL, Fujioka K, et al. Rational design of a combination medication for the treatment of obesity. Obesity (Silver Spring) 2009;17:30-9.

33. Greenway FL, Fujioka K, Plodkowski RA, Mudaliar S, Gut- 
tadauria M, Erickson J, et al. Effect of naltrexone plus bupropion on weight loss in overweight and obese adults (COR-I): a multicentre, randomised, double-blind, placebo-controlled, phase 3 trial. Lancet 2010;376:595-605.

34. Apovian CM, Aronne L, Rubino D, Still C, Wyatt H, Burns C, et al. A randomized, phase 3 trial of naltrexone SR/bupropion SR on weight and obesity-related risk factors (COR-II). Obesity (Silver Spring) 2013;21:935-43.

35. Wadden TA, Foreyt JP, Foster GD, Hill JO, Klein S, O’Neil PM, et al. Weight loss with naltrexone SR/bupropion SR combination therapy as an adjunct to behavior modification: the CORBMOD trial. Obesity (Silver Spring) 2011;19:110-20.

36. Hollander P, Gupta AK, Plodkowski R, Greenway F, Bays H, Burns C, et al. Effects of naltrexone sustained-release/bupropion sustained-release combination therapy on body weight and glycemic parameters in overweight and obese patients with type 2 diabetes. Diabetes Care 2013;36:4022-9.

37. Khera R, Murad MH, Chandar AK, Dulai PS, Wang Z, Prokop LJ, et al. Association of pharmacological treatments for obesity with weight loss and adverse events: a systematic review and meta-analysis. JAMA 2016;315:2424-34.

38. Vilsbøll T, Zdravkovic M, Le-Thi T, Krarup T, Schmitz O, Courrèges JP, et al. Liraglutide, a long-acting human glucagonlike peptide- 1 analog, given as monotherapy significantly improves glycemic control and lowers body weight without risk of hypoglycemia in patients with type 2 diabetes. Diabetes Care 2007;30:1608-10.

39. Astrup A, Rössner S, Van Gaal L, Rissanen A, Niskanen L, Al Hakim M, et al. Effects of liraglutide in the treatment of obesity: a randomised, double-blind, placebo-controlled study. Lancet 2009;374:1606-16.

40. Pi-Sunyer X, Astrup A, Fujioka K, Greenway F, Halpern A, Krempf M, et al. A randomized, controlled trial of $3.0 \mathrm{mg}$ of liraglutide in weight management. N Engl J Med 2015;373: 11-22.

41.Le Roux CW, Astrup A, Fujioka K, Greenway F, Lau DC, Van Gaal L, et al. 3 Years of liraglutide versus placebo for type 2 diabetes risk reduction and weight management in individuals with prediabetes: a randomised, double-blind trial. Lancet 2017;389:1399-409.
42. Shimoda M, Kanda Y, Hamamoto S, Tawaramoto K, Hashiramoto M, Matsuki M, et al. The human glucagon-like peptide-1 analogue liraglutide preserves pancreatic beta cells via regulation of cell kinetics and suppression of oxidative and endoplasmic reticulum stress in a mouse model of diabetes. Diabetologia 2011;54:1098-108.

43. Mari A, Degn K, Brock B, Rungby J, Ferrannini E, Schmitz O. Effects of the long-acting human glucagon-like peptide-1 ana$\log$ liraglutide on beta-cell function in normal living conditions. Diabetes Care 2007;30:2032-3.

44. Vilsbøll T, Brock B, Perrild H, Levin K, Lervang HH, Kølendorf K, et al. Liraglutide, a once-daily human GLP-1 analogue, improves pancreatic B-cell function and arginine-stimulated insulin secretion during hyperglycaemia in patients with type 2 diabetes mellitus. Diabet Med 2008;25:152-6.

45. Stratton IM, Adler AI, Neil HA, Matthews DR, Manley SE, Cull CA, et al. Association of glycaemia with macrovascular and microvascular complications of type 2 diabetes (UKPDS 35): prospective observational study. BMJ 2000;321:405-12.

46. American Diabetes Association. 10. Microvascular complications and foot care: Standards of Medical Care in Diabetes2018. Diabetes Care 2018;41(Suppl 1):S105-18.

47. Tong PC, Lee ZS, Sea MM, Chow CC, Ko GT, Chan WB, et al. The effect of orlistat-induced weight loss, without concomitant hypocaloric diet, on cardiovascular risk factors and insulin sensitivity in young obese Chinese subjects with or without type 2 diabetes. Arch Intern Med 2002;162:2428-35.

48. Scirica BM, Bohula EA, Dwyer JP, Qamar A, Inzucchi SE, McGuire DK, et al. Lorcaserin and renal outcomes in obese and overweight patients in the CAMELLIA-TIMI 61 trial. Circulation 2019;139:366-75.

49. Mann JF, Ørsted DD, Brown-Frandsen K, Marso SP, Poulter NR, Rasmussen S, et al. Liraglutide and renal outcomes in type 2 diabetes. N Engl J Med 2017;377:839-48.

50. Miles JM, Leiter L, Hollander P, Wadden T, Anderson JW, Doyle $\mathrm{M}$, et al. Effect of orlistat in overweight and obese patients with type 2 diabetes treated with metformin. Diabetes Care 2002;25:1123-8.

51. Nissen SE, Wolski KE, Prcela L, Wadden T, Buse JB, Bakris G, et al. Effect of naltrexone-bupropion on major adverse cardio- 
vascular events in overweight and obese patients with cardiovascular risk factors: a randomized clinical trial. JAMA 2016; 315:990-1004.

52. Marso SP, Daniels GH, Brown-Frandsen K, Kristensen P, Mann JF, Nauck MA, et al. Liraglutide and cardiovascular outcomes in type 2 diabetes. N Engl J Med 2016;375:311-22.
53. Davies MJ, Aronne LJ, Caterson ID, Thomsen AB, Jacobsen PB, Marso SP, et al. Liraglutide and cardiovascular outcomes in adults with overweight or obesity: a post hoc analysis from SCALE randomized controlled trials. Diabetes Obes Metab 2018;20:734-9. 